\title{
PERUBAHAN KADAR KEASAMAN, INTENSITAS AROMA, DAN KESUKAAN YOGURT DRINK SETELAH FORTIFIKASI EKSTRAK SALAK
}

\section{THE CHANGE OF ACIDITY, AROMATIC INTENSITY AND ORGANOLEPTIC PROPERTIES OF YOGURT DRINK FORTIFIED BY SALAK FRUITS EXTRACTS}

\author{
Selma Noor Permadi ${ }^{1)}$, Anang Mohamad Legowo ${ }^{2)}$, Yoyok Budi Pramono ${ }^{2)}$, Ahmad \\ Nimatullah Al-Baarri ${ }^{1)}$ \\ 1) Program Studi Magister Ilmu Ternak, Fakultas Peternakan dan Pertanian,Universitas Diponegoro, Semarang \\ ${ }^{2)}$ Program Studi Teknologi Pangan, Fakultas Peternakan dan Pertanian, Universitas Diponegoro \\ email: Selma.bukan.salma@gmail.com dan 085641649649
}

\begin{abstract}
This study aims to determine the effect of extracts salak fruits in maintaining the quality of the yogurt drink seen from acidity and organoleptic quality properties. Organoleptic properties consist of fruit taste and preferences . Materials used include, skim milk, salak fruits, starter cultures ( L. bulgaricus, S. thermophillus, L. acidophillus, and B. longum ATCC 15707 ), deMan Rogosa Sharpe ( MRS ) broth, distilled water, galactose and sistein HCL. The method used in this study include, methods of making of yoghurt starter work, a method of making a starter work B. longum ATCC 15707, methods of making salak fruits extracts, the method of making yogurt drink, and testing methods used. Experiment was a completely randomized design ( CRD ) 4 treatments and 5 replications. The treatments were the addition of extracts salak fruits in yogurt drink ( v/v ) at : $\quad \mathrm{T} 0=0 \% ; \mathrm{T} 1=1 \%$; $\mathrm{T} 2=2 \%$, and T3 $=3 \%$. Data were analyzed using analysis of variance to determine the effect of treatment. Acidity of the yogurt drink produced ranged from 0.74 to 0.98 and organoleptic properties include influential taste while A does not affect the resulting yogurt drink.
\end{abstract}

Keywords: yogurt drink, acidity, organoleptic properties

\begin{abstract}
ABSTRAK
Penelitian ini bertujuan untuk mengetahui pengaruh penambahan ekstrak buah salak dalam mempertahankan mutu yogurt drink dilihat dari keasaman dan mutu sifat organoleptik. Sifat organoleptik terdiri dari cita rasa buah dan kesukaan. Bahan yang digunakan meliputi, susu skim, buah salak, kultur starter (L. bulgaricus, S. thermophillus, L. acidophillus, dan B. longum ATCC 15707), deMan Rogosa Sharpe (MRS) broth, aquades, galaktosa dan sisteinHCL. Metode yang digunakan dalam penelitian ini meliputi, metode pembuatan starter kerja yogurt, metode pembuatan starter keja B. longumATCC 15707,metode pembuatan ektrak buah salak, metode pembuatan yogurt drink, dan metode pengujian variabel.Rancangan percobaan yang digunakan adalah rancangan acak lengkap (RAL) 4 perlakuan dan 5 ulangan. Perlakuan yang diberikan adalah penambahan ekstrak buah salak dalam yogurt drink (v/v) sebesar: T0 =0\%; T1 =1\%; T2 =2\%; dan T3 =3\%.Data penelitian diolah dengan menggunakan sidik ragam untuk mengetahui pengaruh perlakuan.Keasaman yogurt drink yang dihasilkan berkisar antara 0,74-0,98 dan sifat organoleptik yang meliputi cita rasa berpengaruh sedangkan untuk kesukaan tidak mempengaruhi yogurt drink yang dihasilkan.
\end{abstract}

Kata Kunci: yogurt drink, keasaman, sifat organoleptik

\section{PENDAHULUAN}

Yogurt drink, merupakan yogurt yang dibuat berdasarkan cara pembuatan stirred yogurt, tetapi gumpalan yang terbentuk dihancurkan hingga berupa cairan sebelum dikemas (Legowo et al., 2009). Yogurt drink berbasis susu rendah lemak yang hanya mengandung 0,5-2\% lemak, atau bahkan skim tanpa lemak. (Astawan, 2009). Pada fermentasi susu menjadi yogurt terdapat lima bakteri yang dapat digunakan, yaitu Lactobacillus acidophilus (asidofilus, atau disingkat A), Bifidobacterium bifidum (bakteri bifidus, disingkat B), Lactobacillus casei, Streptococcus thermophilus, dan Lactobacillus bulgaricus. Yogurt atau kefir sendiri sering disebut makanan probiotik (Widodo, 2002). Perkembangan teknologi dan perubahan pada pola konsumsi telah mengakibatkan permintaan yogurt meningkat sehingga mendorong produksi yogurt yang lebih bervariasi,baik dari segi jenis, tekstur, aroma, maupun rasa (Hidayat at al., 2006). Salah satunya dengan memanfaatkan buah lokal Jawa Tengah yakni buah salak yang produksinya berlimpah, tidak mengenal musim, dan olahan yang berbasis buah salak masih relatif sedikit. Buah salak di Jawa Tengah 
merupakan buah unggulan dengan produksi terbanyak ke-2 dengan jumlah 443,840 ton (BPS, 2012). Kadar gula buah salak berkisar antara 39,32\% bk - 93,02\% bk pada masa panen umur

5-6,5 minggu. Pada umumnya buah mengandung gula dalam bentuk monosakarida (fruktosa dan glukosa) dan disakarida(sukrosa) (Kiswanto, 2004).

\section{METODE PENELITIAN}

\section{Bahan dan Alat}

Bahan yang digunakan dalam penelitian ini antara lain susu skim, buah salak, kultur starter (L. bulgaricus, $S$. thermophillus, $L$. acidophillus dan $B$. longum ATCC 15707), deMan Rogosa Sharpe (MRS) broth dan agar, aquades, galaktosa dan sistein $\mathrm{HCl}$.

Alat yang digunakan dalam pembuatan yogurt drink: autoklaf, inkubator, refrigerator, termometer, micropipet, alumunium foil, bunsen, erlemeyer, pisau, telenan, mangkuk, kultur tube, sentrifuge, kain filter.

\section{Pembuatan starter kerja yogurt}

Pembuatan starter kerja yogurtdibuat dengan metode Hartati (2011) yang terdiri 3 kombinasi BAL yaitu L. bulgaricus, $S$. thermophillus, dan L. acidophillus dibuat dengan cara menimbang bibit serbuk yogurtyang terdiri dari campuran 3 bakteri tersebut sebanyak 3,5g, dimasukkan kedalam erlemeyer dan ditambah air steril sebanyak25 ml, dikocok hingga homogen. Kemudian dimasukkan ke dalam inkubator selama 12 jam pada suhu $41^{\circ} \mathrm{C}$. Lalu ditambahkan susu Ultra High Temperature (UHT) fullcream sebanyak $50 \mathrm{ml}$ ke dalam bibit cair yogurt tersebut dan diinkubasi lagi selama 6 jam pada susu $41^{\circ} \mathrm{C}$ (F1). Setelah inkubasi selesai, bibit cair yogurt dibiakkan lagi dari $25 \mathrm{ml}$ starter (F1) ke dalam $500 \mathrm{ml}$ susu UHT diinkubasi selama 6 jam pada suhu $41^{\circ} \mathrm{C}$ (F2). Selanjutnya starter kerja dibuat (bulk starter) dengan dibiakkan $25 \mathrm{ml}$ starter (F2) dalam $500 \mathrm{ml}$ susu UHT diinkubasi selama 6 jam pada suhu $41^{\circ} \mathrm{C}$ (F3) hingga $\mathrm{pH}$ 4,4-4,5 dengan kepadatan $10^{8} \mathrm{CFU} / \mathrm{ml}$.

\section{Pembuatan starter kerja $B$. longum ATCC 15707}

Pembuatan starter kerja B.longum ATCC 15707dibuat dengan metode Samona and Robinson (1991). Starter dibuat dari ampul bubuk yang kemudian dibiakkan dalam media MRS broth sebanyak $14 \mathrm{ml}$ dengan ditambahkan sistein HCL dan galaktosa masing-masing $0,2 \mathrm{ml}$ dan diikubasi selama 24 jam pada suhu $37^{\circ} \mathrm{C}$ (F1). Untuk menjadikan starter kerja dengan melakukan peremajaan dari F1 ke F2 dengan diambil 0,14 ml (1\%) F1 dan dimasukkanke dalam $14 \mathrm{ml}$ MRS broth serta ditambahkan sistein HCL dan galaktosa masing-masing $0,2 \mathrm{ml}$ dan diikubasi selama 24 jam pada suhu $37^{\circ} \mathrm{C}$ (F2). Selanjutnya dikondisikan F2 menggunakan media susu dengan ditambahkan 10\% F2 ke dalam $100 \mathrm{ml}$ susu skim UHT dan diinkubasi pada suhu $41^{\circ} \mathrm{C}$ selama 4 jam sehingga didapatkan F3. F3 merupakan starter kerja dengan $\mathrm{pH}$ 5,5-5,6 dengan kepadatan starter $10^{8} \mathrm{CFU} / \mathrm{ml}$.

\section{Pembuatan ekstrak buah}

Proses pembuatan ekstrak buah salak yaitu buah tanpa biji ditimbang $100 \mathrm{~g}$. Kemudian dihaluskan dengan mortar. Ekstrak buah yang telah halus difilter dengan menggunakan kain filter kerapatan 2025 mesh rangkap 2 sebanyak 2 kalidan dilakukan prosedur sentrifugasi menggunakan sentrifuge $6000 \mathrm{rpm}$ selama 10 menit, hal ini dilakukan untuk mendapatkan hasil yang sempurna yang bebas serat. Setelah itu, ekstrak buah salak diberi perlakuan laktoperoksidasi sistem sebanyak 20\% dari volume ekstrak buah yang berfungsi untuk menghilangkan bakteri-bakteri patogen yang dapat mengganggu proses pembuatan yogurt drink.

\section{Pembuatan yogurt drink}

Proses pembuatan yogurt drink sesuai metode Legowo et al., (2009) yaitu dilakukan dengan susu skim dipasteurisasi pada suhu $80^{\circ} \mathrm{C}$ selama 15 menit setelah selesai diturunkan suhunya hingga $41^{\circ} \mathrm{C}$. Susu diinokulasi dengan starter yang telah dipersiapkan sebelumnya sebanyak $3 \% \mathrm{v} / \mathrm{v}$ starter campuran L. bulgaricus, $S$. 
thermophillus, dan L. acidophillus dan 1\% v/v starter B. longum ATCC 15707dengan kepadatan starter $10^{8} \mathrm{CFU} / \mathrm{ml}$. Setelah itu diinkubasi pada suhu $41^{\circ} \mathrm{C}$ selama 3 jam hingga jumlah bakteri mencapai $10^{6} \mathrm{CFU} / \mathrm{ml}$ dan $\mathrm{pH}$ 4,7-4,8. Kemudian ditambahkan ekstrak salak pada jam ke-3 sesuai perlakuan dan diinkubasi kembali pada suhu $41^{\circ} \mathrm{C}$ selama 2 jam hingga jumlah bakteri mencapai $10^{8} \mathrm{CFU} / \mathrm{ml}$. Yogurt drink disimpan dalam refrigerator dengan suhu $5^{\circ} \mathrm{C}$.

\section{Metode pengujian keasaman}

Pengujian keasaman dilakukan dengan menghitung kadar asam setara asam laktat dengan metode titrasi (Hadiwiyoto, 1994). Yogurt drink yang akan diukur keasamannya diambil sampelnya sebanyak $20 \mathrm{ml}$ untuk dititrasi. Sebelum dititrasi sampel ditetesi fenolftalin $1 \%$ sebanyak 2 tetes, setelah itu sampel dititrasi dengan $\mathrm{NaOH} 0,1 \mathrm{~N}$ sampai terlihat warna merah muda konstan. Perhitungan kadar asam dilakukan dengan rumus :

$$
\text { Kadar asam }=\frac{\mathrm{V}_{1} \times \mathrm{N} \times \mathrm{B}}{\mathrm{V}_{2} \times 1000} \times 100 \%
$$

Keterangan:

$\mathrm{V}_{1}$ : Volume $\mathrm{NaOH}(\mathrm{ml})$

$\mathrm{V}_{2}$ : Volume sampel (ml)

$\mathrm{N}$ : Normalitas $\mathrm{NaOH}(0,1 \mathrm{~N})$

$\mathrm{B}$ : Berat molekul asam laktat (90)

\section{HASIL DAN PEMBAHASAN}

\section{Keasaman Yogurt Drink}

Penambahan ektrak buah salak dalam pembuatan yogurt drink mempunyai dampak positif terhadap keasaman. Buah salak dapat meningkatkan keasaman yogurt drink sesuai standart yang dapat dilihat pada Tabel 1.

Nilai keasaman yogurt drink dengan penambahan buah salak yang tertera pada Tabel 1 berkisar antara 0,74-0,98. Hal ini sesuai dengan SNI 2981:2009yang menyatakan bahwa keasaman yogurt berkisar 0,5-2,0\%. Nilai keasaman pada yogurt biasanya berhubungan dengan kandungan protein pada bahan baku yang digunakan yakni susu. Pada penelitian ini menggunakan susu skim yang kaya protein dan rendah lemak. Koswara (1995) penurunan $\mathrm{pH}$ akan berakibat pada peningkatan keasaman yogurt akibat peningkatan asam laktat. Kasein merupakan protein utama dalamsusu yang terpengaruh olehperubahan $\mathrm{pH}$ atau keasaman ini. Jika $\mathrm{pH}$ susu menjadi sekitar 4,6 atau lebih rendah, maka kasein tidak stabil dan terkoagulasi (menggumpal) sehingga membentuk gel pada yogurt. Gel yogurt ini berbentuk semi solid (setengah padat) dan menentukan tekstur yogurt. Selain berperandalam pembentukan gel yogurt, asam laktat juga memberikan ketajaman rasa, rasa asamdan menimbulkan aroma khas pada yogurt. Ditambahkan Askar dan Sugiarto (2005) asam yang terkandung dalam yogurt merupakan produk utama yang dapat merupakan ciri khas rasa yogurt. Asam ini terbentuk dari hasil fermentasi karbohidrat susu (laktosa) oleh bakteri menjadiasam laktat. Bakteri memanfaatkan laktosa sebagai sumber energi dan sumber karbon selama masapertumbuhan .

\section{Cita Rasa Yogurt Drink}

Cita rasa yang diharapkan dalam yogurt drink dengan penambahan ekstrak buah salak yakni terdapat rasa buah salak dalam yogurt drink yang dihasilkan. Berdasarkan analisis statistik bahwa buah salak memberikan pengaruh terhadap cita rasa yogurt drink, terutama pada penambahan ekstrak buah salak sebesar 3\% yang berkriteria tidak berasa buah sampai agak berasa buah. Hasil analisis statistik cita rasa yogurt drink dapat dilihat pada Tabel 2.

Buah salak merupakan buah yang memiliki rasa sepet dan manis, hal ini ditunjang kadar gula buah salak yang tinggi berkisar antara antara 39,32\% bk - 93,02\% bk pada masa panen umur 5-6,5 minggu. Pada umumnya buah mengandung gula dalam bentuk monosakarida (fruktosa dan glukosa) dan disakarida (sukrosa) (Kiswanto, 2004). Bakteri asam laktat dapat menggunakan kandungan gula yang tinggi dalam buah salak dalam proses fermentasi. Hal ini dimungkinkan dapat memberikan cita rasa pada yogurt drink. Nilai keasaman yang dihasilkan oleh yogurt drink dengan 
Tabel 1. Rerata Keasaman Yogurt Drink dengan Penambahan Ekstrak Buah Salak

\begin{tabular}{ccccc}
\hline \multirow{2}{*}{ Ulangan } & & \multicolumn{3}{c}{ Nilai Keasaman } \\
& T0 $(0 \%)$ & T1 $(1 \%)$ & T2 $(2 \%)$ & T3 $(3 \%)$ \\
\hline 1 & 0,68 & 0,86 & 0,85 & 0,89 \\
2 & 0,71 & 0,90 & 0,94 & 1,09 \\
3 & 0,78 & 0,97 & 0,99 & 0,96 \\
4 & 0,72 & 0,82 & 1,06 & 0,99 \\
5 & 0,83 & 0,88 & 0,95 & 0,97 \\
\hline Rerata & $0,74^{\mathrm{c}} \pm 0,06$ & $0,89^{\mathrm{b}} \pm 0,05$ & $0,96^{\mathrm{ab}} \pm 0,08$ & $0,98^{\mathrm{a}} \pm 0,07$ \\
\hline
\end{tabular}

Keterangan : Superskrip yang berbeda pada baris rerata menunjukkan perbedaan yang nyata $(\mathrm{P}<0,05)$

Tabel 2. Sifat Organoleptik Cita Rasa Yoghurt Drink

\begin{tabular}{|c|c|c|}
\hline $\begin{array}{l}\text { Tingkat penambahan } \\
\text { ekstrak buah salak }\end{array}$ & Rata-rata nilai & Kriteria \\
\hline T0 $(0 \%)$ & $1,84^{\mathrm{b}}$ & Sangat tidak berasa buah - tidak berasa buah \\
\hline $\mathrm{T} 1(1 \%)$ & $1,68^{\mathrm{c}}$ & Sangat tidak berasa buah - tidak berasa buah \\
\hline $\mathrm{T} 2(2 \%)$ & $1,68^{\mathrm{d}}$ & Sangat tidak berasa buah - tidak berasa buah \\
\hline $\mathrm{T} 3(3 \%)$ & $2,40^{\mathrm{a}}$ & Tidak berasa buah - agak berasa buah \\
\hline \multicolumn{3}{|c|}{ Keterangan : Superskrip yang berbeda pada kolom rerata menunjukkan perbedaan yang sangat nyata $(\mathrm{P}<0,01)$} \\
\hline \multicolumn{3}{|c|}{ Tabel 3. Kesukaan Yogurt Drink } \\
\hline $\begin{array}{l}\text { Tingkat penambahan } \\
\text { ekstrak buah salak }\end{array}$ & Rata-rata nilai & Kriteria \\
\hline T0 $(0 \%)$ & 2,10 & Sangat tidak suka - tidak suka \\
\hline $\mathrm{T} 1(1 \%)$ & 1,91 & Amat sangat tidak suka - tidak berasa \\
\hline $\mathrm{T} 2(2 \%)$ & 1,80 & Amat sangat tidak suka - tidak suka \\
\hline $\mathrm{T} 3(3 \%)$ & 2,26 & Sangat tidak suka - tidak suka \\
\hline
\end{tabular}

penambahan ekstrak buah salak yang berpengaruh nyata juga mempengaruhi cita rasa yogurt drink. Menurut Winarno (1997) asam laktat merupakan produk yang dihasilkan BAL sebagai aktivitas fermentasi gula, sehingga kadar asam laktat ini dipengaruhi oleh total bakteri asam laktat. Selain itu asam laktat yang dihasilkan mungkin juga dipengaruhi oleh jenis bakteri yang digunakan. Dalam penelitian ini digunakan starter Lactobacillus acidophillus dan Bifidobacterium longum yang mempunyai jalur pembentukan asam laktat yang berbeda. Menurut Salminen et al (2004) Lactobacillus acidophillus termasuk genus Lactobacillus yang merupakan bakteri asam laktat dengan jalur fermentasi homofermentatif sehingga menghasilkan produk mayoritas asam laktat. Sedangkan Bifidobacterium longum termasuk genus Bifidobacterium mempunyai jalurnya sendiri dalam pembentukan asam laktat. Bifidobacterium longum aktif memfermentasi karbohidrat dengan produk utama asam laktat dan asetat laktat.Ditambahkan Koswara (1995) selain berperandalam pembentukan gel yogurt, asam laktat juga memberikan ketajaman rasa, rasa asamdan menimbulkan aroma khas pada yogurt.

\section{Kesukaan Yogurt Drink}

Kesukaan yogurt drink dengan penambahan ekstrak buah salak ini diharapkan dapat diterima oleh masyarakat. Data analisis statisktik sifat organoleptik kesukaan yogurt drink dapat dilihat pada Tabel 3. Hasil analisis statistik sifat organoleptik khususnya kesukaan tidak berpengaruh terhadapat yogurt drink dengan penambahan ekstrak buah salak yang dihasilkan.

Uji kesukaan disebut juga uji hedonik. Dalam uji kesukaan panelis diminta tanggapan pribadinya tentang kesukaan atau sebaliknya. Disamping panelis mengemukakan tanggapan senang, 
suka atau kebalikannya, mereka juga mengemukakan tingkat kesukaannya (Soekarto, 1985). Ditambahkan Kartika et al. (1988) uji kesukaan panelis diminta untuk mengemukakan pendapatnya secara spontan, tanpa membandingkan dengan sampel standar. Pengujian ini umumnya digunakan untuk mengkaji reaksi konsumen terhadap suatu bahan atau memproduksi reaksi konsumen terhadap sampel yang diujikan.

\section{KESIMPULAN}

Penambahan ekstrak buah salak mampu mempengaruhi yogurt drink pada keasaman dan cita rasa sedangkan untuk kesukaan penambahan ekstrak buah salak tidak berpengaruh. Penambahan ekstrak buah salak sebesar 3\% masih dapat mempertahankan mutu yogurt yang dihasilkan, sehingga dimungkinkan dengan memperbesar penambahan ekstrak buah salak mutu yogurt drink masih dapat dipertahankan.

\section{DAFTAR PUSTAKA}

Askar, S. dan Sugiarto. 2005. Uji kimiawi dan organoleptik sebagai uji mutu yoghurt. Prosiding Temu Teknis Nasional Tenaga Fungsional Pertanian.

Astawan, M. 2009. Sehat dengan Hidangan Hewani. Penebar Swadaya, Jakarta.

Badan Pusat Statistik (BPS). 2010. Produksi Buah Menurut Provinsi. www.bps.go.id. (Diakses tanggal 10 juli 2012).

Hadiwiyoto, S. 1994. Teori dan Prosedur Pengujian Mutu Susu dan Hasil Olahannya. Liberty, Yogyakarta.
Hidayat, N., M.C Padaga, dan S. Suhartini. 2006. Mikrobiologi Industri. Andi offset, Yogyakarta.

Kartika, B., P. Hastuti dan W. Supartono. 1988. Pedoman Uji Inderawi Bahan Pangan. Pusat Antar Universitas Pangan dan Gizi Universitas Gadjah Mada, Yogyakarta.

Kiswanto, Y. 2004. Pengaruh umur panen terhadap kadar gula, kadar asam dan tanin pada buah salak pondoh varietas manggala. Jurnal: Buletin Agro Industri No. 27 th 2004.

Legowo, A. M., Kusrahayu dan S. Mulyani. 2009. Ilmu dan Teknologi Pengolahan Susu. Universitas Diponegoro, Semarang.

Salminen, S.; A. von Wright and A. Ouwehand. 2004. Lactic Acid Bacteria Microbiological and Functional Aspects, Third Edition. Marcel Dekker, Inc : NewYork.

Soekarto, S. T. 1985. Penilaian Organoleptik (untuk Industri Pangan dan Hasil Pertanian). Penerbit Bharata Karya Aksara, Jakarta.

Standarisasi Nasional Indonesia (SNI). 2981:2009. Yoghurt. Badan Standardisasi Nasional (BSN), Jakarta.

Widodo, W. 2002. Bioteknologi Fermentasi Susu. Universitas Muhamadiyah Malang, Malang.

Winarno, F. G. dan I. E. Fernandez. 2007. Susu dan Produk Fermentasinya. M-brio Press, Bogor. 